\title{
ДІАЛЕКТИЗМИ В РОМАНІ МАРІЇ МАТІОС «СОЛОДКА ДАРУСЯ»
}

Колоїз Ж. В. Діалектизми в романі Марії Матіос «Солодка Даруся».

У статті йдеться про діалектизми, засвідчені в романі Марії Матіос «Солодка Даруся»; аналізуються їхні фонетичні, лексичні, семантичні, фразеологічні та граматичні різновиди. Зроблено спробу систематизувати передусім діалектну лексику та фразеологію 3 урахуванням структурних, семантичних, функціональностилістичних, а подекуди й генетичних особливостей.

Ключові слова: діалектизм, діалектна лексика, діалектна фразеологія, діалектні особливості.

Колоиз Ж. В. Диалектизмы в романе Марии Матиос «Сладкая Даруся».

В статье рассматриваются диалектизмы, представленные в романе Марии Матиос «Сладкая Даруся»; анализируются их фонетические, лексические, семантические, фразеологические и грамматические разновидности. Сделана попытка систематизировать прежде всего диалектную лексику и фразеологию с учетом структурных, семантических, функционально-стилистических, а отчасти и генетических особенностей.

Ключевые слова: диалектизм, диалектная лексика, диалектная фразеология, диалектные особенности.

Koloiz Z. V. Dialecticisms in novel of Mariya Matios "Sweet Darusya".

The article deals with dialecticisms in novel of Mariya Matios "Sweet Darusya", their phonetical, lexical, phraseological and grammatical types are analyzed. The attempt of systematization of dialect vocabulary and phraseology with taking into consideration their structural, semantic, functional-stylistic and genetic peculiarities are made.

Key words: dialecticism, dialect vocabulary, dialect phraseology, dialect peculiarities.

Найвідоміший і найпопулярніший роман Марії Матіос «Солодка Даруся» - «драма на три життя», як визначає жанр твору сама авторка, це передовсім «моральне застереження-забобон про те, що історія і кожна окрема людина «за всіх часів і режимів пов'язані одною пуповиною, а гріх і його спокута - явища майже осяжні, матеріальні» [6, с. 4]. Безапеляційно: «це - явище в літературі», яке заслуговує на належне поцінування. I не тільки 3 боку літераторів. Адже «Солодка Даруся», як справедливо зауважує Ігор Римарук, - «це данина пам'яті. А також (чи передовсім?..) нашій мові» [6, с. 7]. А відтак лінгвістичні аспекти твору (як, безумовно, й усього творчого доробку письменниці) неодмінно сприятимуть появі грунтовних мовознавчих розвідок. Чого варті одні лише «фразеологічні перлини народної мудрості», які вміло вводяться в контексти, обіграються, трансформуються, перефразовуються й «викликають до життя» нові метафоричні вирази та афористичні моральні формули: Але це таки правда, щзо нікому так не є погано, як нашим ворогам, коли нам добре [c. 68]; Не тільки люди, але й сатана нервує, коли комусь добре трохи довще, ніж собі планує сатана [с. 70]; ... як ніколи не звертає уваги 
дворукий на руки, а двоногий - на ноги [с. 73]; Якби кожен вигнав свою біду на иаринку та добре роздивився б, то бігом хапав би свою назад, бо в другого ще гірша [с. 126]; Людська зависть - гірше, як слабість [с. 168].

3-поміж розмаїття стилістичних засобів мови роману виокремлюються насамперед діалектизми, які допомагають авторці колоритно змалювати «українську історію $30-\mathrm{x}-70$-х років минулого століття в її буковинському і галицькому варіантах» [6, с. 4].

Мета нашої статті полягає в тому, аби систематизувати багатющий діалектний матеріал, репрезентований письменницею, виявити діалектні особливості на різних мовних рівнях (фонетичному, словотвірному, граматичному, лексичному і фразеологічному).

Як відомо, територіальний діалект - різновид національної мови, якому властива відносна структурна близькість i який $\epsilon$ засобом спілкування людей, об'єднаних спільністю території, а також елементів матеріальної i духовної культури, історично-культурних традицій, самосвідомості. Звідси, відповідно, дослідження діалектизмів $є$ актуальним як з позицій вивчення мовної системи загалом, так і можливості пізнання культури й історії народу. 3 одного боку, вони допомагають з'ясувати внутрішні закономірності еволюції літературної мови, 3 іншого, сприяють усебічному розв'язанню питання про історичні зв'язки літературної мови та діалектів.

Кількість українських діалектів, їхні межі i т. ін. $є$ наслідком племінної диференціації 3 доісторичних часів, пізніших різночасових політико-адміністративних об'єднань і перегрупувань земель, наявності і зміни впродовж тривалого періоду розвитку мови етносу адміністративних, культурних, релігійних та освітніх центрів [1; 4]. Цілком очевидно, що структурні особливості того чи того діалекту з часом зазнають змін унаслідок міждіалектної взаємодії та впливу літературної мови. Цей складний і тривалий процес зумовлений сучасними формами виробництва, наявністю в селах і містечках великої кількості інтелігенції, впливом школи, преси, художньої літератури, радіо, телебачення і т. ін. [5, с. 3-9]. Проте діалект як форма існування національної мови не зникає, а лише трансформується в нову якість. Крім того, зміни в різних діалектах і говірках того самого діалекту відбуваються нерівномірно: інтенсивніші спостерігаються поблизу великих економічних, культурних центрів; менш відчутні - у маргінальних та відносно ізольованих природними умовами говірках. Діалектна мова мешканців маленького буковинського Черемошного у прикордонній зоні з Румунією - села, яке пережило окупацію румун, австріяків, москалів, німців, зазнає відповідних впливів, що наочно репрезентує матеріал аналізованого твору. Наприклад: - $A$ щъо, таздику, йдете сього вечір до кобіти? [с. 103], де кобіта - «жінка, любка» (пор. пол.: kobieta); Вуйко Василь - материн брат у третьому - дивився на Михайла і співчутливо, і сердито водночас: він добре розумів, яка біда 
наздогнала його свояка, але не розумів, якої помочі просить у старого газди, щзо тримає в Бозні полонину [с. 164], де вуйко - «дядько по материній лінії» (пор. пол.: wujek); Нічого не трафилося [с. 106], де трафилося - «трапилося; сталося» (пор. нім.: treffen - «попадати (у ціль); траплятися»); маніфестується і як компонент фразеологічної одиниці: ... вже й сваритися із своїм Славком передумала, а він усе ж не каліка... иляк би го був трафив ще в моїи утробі, як мені дні коротає тою горілкою, згорів би був, дай Боже [с. 10-11] (пор. нім.: Schlag soll das treffen - «удар би в тебе стався»); Бо світилися Цвичкові ребра крізь сорочку - і не знати, чи то фамілія його така була худа, чи то неприкаяне життя так висушило чоловіка [с. 47], де фамілія - «родина, рідня» (пор. нім: die Familie); Але, дивіться, вони собі файно любляться, ніби вчора побралися, і живуть тихонько, як миші за лубом [с. 126], де файно «гарно» (пор. нім: fein); Але на відьму вона не виглядна. Не виглядна - $i$ фертик [с. 115], де фертик - «по всьому, кінець» (пор. нім.: fertig «готовий»). Німецьке за походженням фертик вступає в синонімічні відношення 3 українською прийменниково-займенниковою конструкцією по всьому (Скрутилися, як равлики, та й по всьому...Пропали - та й по всьому [с. 10]) і румунською лексемою тата (А так нема корови - як би й не було. Чудо - та й таma [c. 114]). Ілюструється так званий лексичний паралелізм.

Мадяризм газда (gazda) - «господар; добрий господар» стає дериваційною базою для похідних газдиня, газдівський, газдовитий, газдувати і т. ін. (пор. пол.: gazda, gazdowstwo, gazdowač, gazdowanie). Наприклад: Газдику тречний, я знав, щуо ви газда, але ніколи би не подумав, щзо ви так фальшиво дитину свою вчите! [с. 23] (пор. також нім.: falsch«неправильний, помилковий»); Розбита, із запаленими очима, Даруся на ранок бігала від хати до хати, носила порожне горнятко із слідами молока на денці, показуючи його перед очі газдиням [с. 34]; Михайло в тому не розуміє, бо то газдівства не стосується, а його інтересує лиш робота i господарка [c. 104]; Переказували люди з Галіції, щуо стільки звідти самих газдовитих людей забрали у світ, $і$ навіть фамілія не знає, де вони й щзо вони [с. 112]; Дехто, а особливо маєтні газди, усміхалися у вус $i$ відмовляли - i тодi, Михайло не міг би сказати, як таке трафилося, але він перечікував у травах чи під стаями доти, доки не можна було вкрасти з видного місияя бодай кулачок масла [с. 165]; ...за других румунів газдував онук колишнього черемошнянського дідича Флорескула - Флоря, $і$ який зник разом з Лупуловими вояками, покинувши свої великі статки напризволяще [c. 140] тощо.

Для вираження значення, закріпленого за лексемою пaн (naнi), свого часу запозиченої з польської мови, використовується й румунське слово домнул (домна) (-Пане-домнуле, а ви бих поміняли свою любку на мою? Може, моя щзе май смачніша? [с. 103]; -Не плачте, домно... - 
якомога лагідніше заспокоӥв лейтенант, але вона вже була в сінях [с. 132]), яке в тексті роману подекуди репрезентовано й не в кириличному оформленні (-Не бійся, domnule Мігаю. Нічого не трафилося. Я лиш прийшов сказати, щзо ми вибираємося із Черемошного [с. 106]). Подібне представлення характерне й для румунської за походженням лексеми гранічер - «прикордонник» (...y забитому в гори селі над Черемомем, цуарями й Богами були королівські посередники - служиві вояки місцевої жандармерії й graniceri на чолі з лейтенантом Лупулом та місцеві дідичі [с. 97]; а з изього боку - поділяться гранічери сушеними сливами в мімуликові, зачепленім до верху довгої і гнучкої ліски чи жердки [с. 101]). Частина румунізмів, як і більшість запозиченої лексики, на українському, зокрема на буковинському грунті, адаптуючись, зазнала помітних фонетичних модифікацій. Наприклад: Він ішов вулицею, геть зовсім байдужий, мовби спорожнілий, як і його бесаги, $і$ дивився перед себе, ні з ким не вітаючись і не відповідаючи на привітання [с. 148], де бесаги - «дві торби, з'єднані одним полотнищем, що їх носять перекинутими через плече» (пор. рум.: deságă).

Помітних модифікацій зазнали деякі русизми, як-от: $У$ двох особливо мілких місиях, там, де каміння шкіриться над гривастою хвилею, ріку пильнують смугасті прикордонні стовпи, один з яких недавно поміняли совіти, але він був майже такий, як при Польщуі, тільки більш хитливий, бо не дуже добре закріплений [с. 98] (пор. рос.: советы); Славка завжди носило, мов крота по городу, а Даруся навіть малою була степенна, розважлива, неначе стара жінка [с. 21] (пор. рос.: остепиниться - «стати розсудливим, розважливим»); Веремінність для газдині, щуо має вінчаного газду, - ие не встид [с. 91], (пор. рос.: беременность - укр.: вагітність). Хоч, цілком імовірно, що стабілізація діалектизму веремінність не $\epsilon$ такою простою, як здається на перший погляд (заміна однієї губної фонеми іншою, шумної сонорною). Адже в галицько-буковинських говірках засвідчений цілий ряд спільнокореневих слів, які можуть «пролити світло» на походження аналізованої лексеми: веремний (веремінний) означає «погідний, ясний», а веремнє - «гарна сонячна погода» (можливо, має стосунок до врємА - «час», тобто йдеться про відповідний тимчасовий стан). Без будь-яких особливих змін уведено в контексти лексему конфета (зазвичай носії того чи того діалекту замінюють звук [ф] на звукосполучення [хв]): Але з людьми вона не хоче говорити, бо тоді вони можуть дати їй конфету [с. 11]; А Даруся знає: Марія думає, щзо ї повидло солодке. Ніяке воно не солодке - терпке, язик $і$ ясна пощзипує. I ніщуо на світі не є солодким, окрім конфет [с. 24] тощо. Очевидно, письменниця робить це свідомо, аби в таких спосіб акцентувати увагу на тому, що саме стало причиною людських страждань, бід, горя, нещасть, причиною «драми на три життя». 
Однак попри довготривале контактування 3 різними наріччями Буковина, буковинські говірки зберігають і специфічно-національні риси. Текст роману репрезентує споконвічні тамтешні народні звичаї і традиції. Наприклад: I иі, мініатюрні здалека, розкидані між срібними, блискучими снігами темні иятки хат світилися тепер веселими вертепними звіздами; i чорніли між хатами тонкі вервечки колядників і маланкарів, як плетені пастуші батіжки [с. 102] (пор.: маланка (Маланка - Свято Меланії Преподобної - 13 січня) $\rightarrow$ маланкувати (щедрувати в новорічну ніч) $\rightarrow$ маланкар (щедрувальник); ... Даруся не розплющувала очей, знаючи, щзо, як тільки відкриє їх, - обручі знову звиють гніздо в бідній ї̈ голівці, як гаддя на Здвиження звиває в землі свої кубла на зиму [с.14], тобто йдеться про свято «Воздвиження Чесного і Животворящого Хреста Господнього», яке в народі називають «Здвиження» (27 вересня за новим стилем). 3 давніх-давен вважали, що на Здвиження земля «движеться» ближче до зими, а тому від цього часу наступають холодні дні і гаддя «звиває в землі свої кубла на зиму». Хронологізація подій не обмежується лише відповідними датами, але й грунтується на церковному календарі. Пор.: $T a$ від минулої осені, відколи побиті німщем поляки вступилися з тамтого краю, а точніше, від 17 вересня 1939 року, у дзеркально відбитому через ріку Черемошному порядкували совіти [с. 98]; ...A по Петрі через Івана з Дарусею знову стало село з ніг на голову: Варвара, до якої припечаталось прізвисько Злодійка, мало не від хати до хати носила новину - аж давилася від нетерплячки [с. 63] (Святих апостолів Петра і Павла 12 липня за новим стилем); ...Напад головного болю тривав на ией раз у Дарусі від другої Богородиці, а ие з 21 вересня, аж до Покрови [с. 75]. У галицько-буковинських говірках лексема Богородиця використовується для позначення релігійного свята - Успіння Пресвятої Богородиці (перша Богородиця, або перша Пречиста, - 28 серпня), 21 вересня (друга Богородиця) - Різдво Богородиці, 4 грудня (третя Богородиця) - Уведення Пречистої Богородиці у Храм). Свято «Покров Пресвятої Богородиці», відоме для більшості українців під назвою Покрова, датується 14 жовтня.

Варто зауважити, що характерні діалектні особливості простежуються на всіх мовних рівнях. $€$ істотні відмінності у звуковому складі, у групах звуків, звукових зв'язках, у взаємопереходах та чергуваннях звуків. Наприклад: Варварою з ї голови і затоптаною під ноги газової косинки $i$ Марї̈них двох кулаків не так у куфайку, як у плечі [с. 51]; - То коли мені ладувати в дорогу рупцак? [с. 132] (пор.: рюкзак); Ци ти думаєи, що инчі будуть раді, щзо їх молока загриміли до таліиейських шугаїв? [с. 165]; А ти пам'ятаєщ, як від ріки можна було видіти польських панів з того боку, завсігди виквасованих, як до шлюбу? [с. 110]; Ой, не пам'ятаєш, ти ще май малий тогди був [c. 110] і т. ін. Окремі зразки демонструють таку фонетичну особливість, як наявність $[o]$ у закритому складі, $[i]$ - на місці секундарного [o]: Колись то, розказують старі люди, у першу войну йшло 
цүим селом изіле кінне войсько, а попереду на білім коні їхав сам Чапаєв чи то Брусилов [с. 51]; А ти подивися на їх офіиеерів, щзо снують селом, як ошеленні. Я на австрийській войні не був старшим офіцером, я був всього лиш стариим куда пішлють - солдатом [с. 111]. Використання слів на зразок война, войсько, очевидно, слід пов'язувати з впливом польської мови (пор.: wojna), у другій ситуації, де морфемна структура слова передбачає префікс ni- (nо- $\leftarrow$ прийменник пz), унаслідок переміщення меж складоподілу в діалектній мові склад стає закритим.

Подекуди автор ілюструє дорсально-палатальну вимову свистячих звуків із відтінком шепелявості: Може, прийдіть мене наймати до кошіння на той тиждень. Але не з понеділка, бо понеділок - тяжкий день... [с. 43]. Спостерігається непослідовне взаємозаступлення шиплячих і свистячих (-Піду поражуся з жінкою, ци позволить [с. 103]), зміна [a] в $[e]$, зокрема після шиплячих, які виникли внаслідок палаталізації, з часом депалаталізувалися і з таким статусом закріпилися в сучасній літературній мові: Хоч ти мені трохи й свояк, але якась ви така фамілія, чоловіче, щзо ліпше ї̈ не мати, вибачєй мені на слові [с. 165], [a] в [и] після м'яких (пом'якшених) звуків, наприклад, губних: ...Ніхто не знав, ma й не допитував ніколи, Іванового прізвищуа, лише відколи світ та сонце люди $i$ діти в Черемошнім призвішкувалися йому Цвичком, бо дуже любив Іван збирати по довколишніх селах залізяччя, а найбільше - цзяхи, потутешньому «цвики», з яких згодом робив дримби і продавав їх чи то в Kymax, чи в Косові на базарі [с. 40]. Поодинокими зразками маніфестується асимілятивне перетворення груп губних: I за тебе, Штефане, порозказую, як ти п'яний за чужими молодицями з револьвером гонишся... і як твоя жінка самогонку варить з колгоспного иукру... можеш не сумліватися...[с. 72], паралельне використання слів зі звуками (звукосполученнями) [кв] і [фp]: Коли Іван ішов до когось на деньку, брав із собою Дарусю, садовив у тінь, давав лущити квасолю чи кукурудзу, а сам колов дрова чи косив, чи закладав вориння, і руки йому співали без музики [c. 68]; Ото Марія ладна була щуодня носити сусідам черепки з борщем чи товченими фасулями, жменьку кулешки, чи кусник сала, щуоб тільки Іван не був голодний, щзоби мав силу грати у дримбу [с. 47], ілюструється так зване «сильне укання»: Перетри фасуль, барабуль та й нагодуй здоровіма буде. А вона ні - лиш циицьковим молоком годувала [с. 113] (пор.: Та Іван частенько завертав Марїні попоїки, показуючи на баняк звареної бараболі чи чавун кулеші [с. 47]; Нема бараболь, лишається жменька мукички, довго ні з чого збити татові масельия - все можна перетерпіти [c. 32]).

Характерне явище так званого гіперизму - непослідовного, несистемного заміщення звуків чи форм задля уникнення ненормативних $\mathrm{i}$ відтворення правильних форм, які, проте, виявляються «правильними» лише в уяві мовців: Чоловік один, а колісниця кожюого разу друга. 
Розумієш, Мойшо? Кождого разу друга! А чоловік один [с. 108]; А тобі скажу таке: не може бути, щоби жадна душа не чула - не виділа сліду твої жінки [с. 109]; Та послухайте, жінко добра, щось то значить, щзо румуни забралися тепер із села під німеџьку команду, як колись маскалі, ніхто не чув, не видів?! [c. 127].

Мова роману репрезентує десь-не-десь і виразні діалектні особливості на словотвірному рівні. Це переважно слова, які відрізняються від літературних відповідними афіксами, здебільшого суфіксами: Вона не вміє жити між людьми із своєю мовою. Люди самі й відучили говорити. То хай терплять німоту. Вона ж терпить їхне дуренство [с. 34]; Якось то був так спаскудив тюдівську молодицю, що біданка до Кутів ходить пішки, аби лиш на Цвичка не втрапити [с. 39]; Бо так дві добі біднятко без цицьки плаче - волосся на голові диба стає [c. 113]; То Іван попросив шкільників зробити по одній ходия і визбирати по селі залізні труби [с. 54], рідше - префіксами: Матронку в селі називають Михайловим чудом. Точніше, Михайло сам ї̈ так призвав [c. 81]; Бо воно ж i таке трапляється: не встигне дівка з-під вінка вибратися, а вже на очі стає розкоса, як по чужих мужчинських лииях застрягає, ніби не має свого [с. 87]. Причому деякі зі слів маніфестують відмінності й на фонетичному рівні.

У «Солодкій Дарусі» засвідчено й ряд граматичних особливостей буковинської говірки. Здебільшого вони пов'язуються з морфологічними ознаками відповідних лексико-граматичних груп слів. Передусім граматичні модифікації стосуються іменних частин мови загалом i іменника зокрема. Художній текст репрезентує як діалектні відмінності родових і числових граматичних характеристик $(O$, весільна хора для того, хто ї̈ чує, звучить, як попередження, ба, швидше - завчасний подзвін, а може, навіть попередній, $i$ дещуо несправедливий вирок тріпотливому з радості людському серию [с. 85] (пор. : у літературній мові хор чоловічого роду); Тоді здуває з хреста порохи, обтирає його марлечкою, по черзі торгає усі чотири стовпиі огорожі і нарешті сідає в ногах давно осілої, майже рівної із землею могилки [с. 30] (пор.: порох - має граматичне значення однини), так і відмінкових. Останні виявляються досить строкато. Так, скажімо, іменник Марія є власною назвою, з позицій літературної мови кваліфікується як такий, що належить до I відміни м'якої групи, а відтак у кличному відмінку має закінчення -е (Mapic), натомість у контексті він дублює закінчення іменників твердої групи: $-\boldsymbol{A}$ виджу, Марійо, ви коло ции двох і собі якась як причмелена стали. Воно й не дивно: сусідство... [с. 38]. У родовому відмінку однини іменники третьої відміни в сучасній літературній мові мають закінчення -i, в аналізованому творі така граматична форма забезпечується флексією $-u: y$ мене також діти, та й до своєї смерти я хочу дожити. Я у гірші часи якось скапав иеї напасти, то й тепер не хочу [с. 165], що відображає давні 
особливості цього типу відмінювання і засвідчує певну незакономірність у «протіканні» історичних фонетичних процесів (пор. староукр.: смь $\rho \mathbf{T h}$ смьютн). Місцевий відмінок однини іменників чоловічого роду II відміни за аналогією до давального відмінка ще у староукраїнській мові розвинув

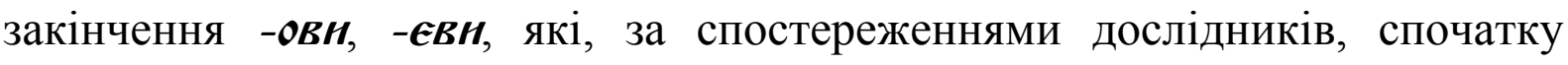
змінилися в -ов $\mathbf{t},-\boldsymbol{\epsilon} \boldsymbol{B}$, а згодом - в -ові, -еві. Діалектна мова фіксує давніші форми: Аж чую - від Довбушевої могили, а ви знаєте, вона якраз у самому кутикови, при самій дорозі, нечиста сила говорить, людським голосом говорить, та страшним таким, як би ведмідь крізь малини дерся [c. 33] (закінчення місцевого відмінка однини іменників другої відміни -ови співвідноситься 3 закінченням -овн іменників давніх $\breve{u}$-основ). Наявність таких граматичних форм у буковинських говірках деякі науковці пояснюють впливом польської мови, де таке закінчення майже витіснило закінчення -y в давальному відмінку. Місцевий відмінок однини іменників середнього роду характеризується непослідовним використанням закінчень -y, -i: Бігме Боже, нібито на весіллю «гуцулку» гуляє, крутиться, руки тримає широко, спідниця догори підфітькується [с. 33]; По закінченні роботи посадив Іван хлопчаків на лавку під хату, сам узяв поливане відро на руку та й пішов у центр до магазину, приніс звідти семикопієчних коржиків, дав кожному дітвакові по одному [с. 49]. Іменник люди в називному відмінку множини в мовленні персонажів, представників Буковини, отримує закінчення -е: ...казали оногде старі люде: не можна так дуже любитися, як изі двоє любилися, - на людей не зважали... [с. 116]. Відмінності пов'язуються й з граматичними формами родового і знахідного відмінків множини: Параска изілим днями ходила поміж хатів, нічого не просячи, нікого не зачіпаючи [с. 20]; Вона тут усе розуміла. Геть чисто все, до найменшої дрібнички, а вертала домів - $i$ все розліталося, ніби висохла соснова шишечка [с. 34]; Так вони й почеберяли: Даруся з кошем попереду, Іван Цвичок із перекинутою почерез плече косою на півкрока позаду, а навкруги них - сільські пси, не загнані господарями в халабуди та не прив'язані на ланци [с. 48]. У першому разі іменники різних типів відмінювання демонструють активізацію закінчення

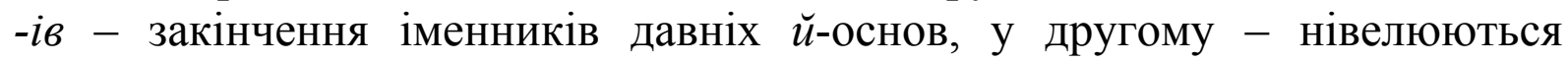
диференційні ознаки твердої / м’якої системи відмінювання іменників II відміни. Слід зауважити, що виразні діалектні особливості стосуються й інших іменникових граматичних значень, приміром, збірності: Хрестіться, дітво, рано і увечір хрестіться, та просіть Бога, аби вас обминула така тяжка судьба [с. 168] (пор.: дітвора); Тобі не пошкодить ні начиння в хату, ні вберя [с. 121] (пор.: вбрання). У контексті представлено, хоч і поодинокими ілюстраціями, залишки граматичних форм колишньої двоїни: Бо решта не могли похвалитися тим, щуо чули від нього більше, ніж дві-три слові [с. 43]; Ви то не дуже у цему розумієтеся, бо баба-челядина не від войни і у воєннім ділі не розуміє ні дві - ні три 
[c. 127] (у староукраїнській мові числівник дв форму для жіночого і середнього родів, на відміну від сучасної, де

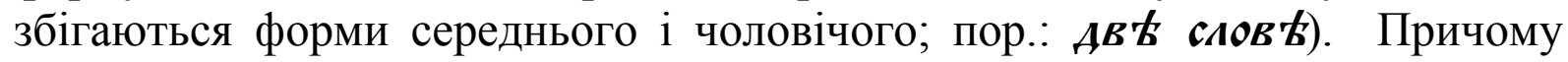
числівник два використовується й при іменниках назвах неістот у значенні збірного: І так собі перегукуються почерез ріку два підпилі тазди - аж на двос сіл, та де там на двоє сіл - на дві держави чути [с. 104].

3-поміж прикметникових говіркових особливостей можна виокремити такі, як: наявність матеріально вираженого закінчення у присвійних прикметниках чоловічого роду в називному відмінку однини та відмінне від літературної мови вираження категорії співвідносної міри якості якісних прикметників: Уже як гуляв увечері татовий пасок по Дарусиній спідничині та по ногах, вона дотепер чує [с. 22] (пор.: татів); -То щзо ти собі думаєш, таке обірване $і$ ніяке, як оце, щчо плює перед дзвіницею, $і$ не знати, де йому пуп рубали, може бути май ліпше чи добріше, як румунський жандарм чи учений дідич? [с. 110] (пор.: найліпше, найдобріше); Кажу вам достеменно, тяжкі часи настали - а будуть ще май тяжчі [с. 127] (пор.: найтяжиі). Спостерігається й перехід прикметників м'якої групи у тверду (А коли вже по великій правдi, то, як на те пішло, нічого иі двоє не хотіли... хіба що хотіли бути окремішними від усього [с. 117]; - Ти, мерзо мерзенна, приймаку дурний, безродне насіння, ти, дурню остатний, що до такої самої дурної пристав, ти злодію таліцейський, паськудо паськудна... я на тебе управу знайду, ще не вродився такий, щоби я на нього управи не знайшла... будеш сидіти за злодійство у криміналі - кістки зогниють тобі в нім... [с. 50]).

Характерною діалектною рисою є залишки енклітичних граматичних форм знахідного відмінка колишніх особових і зворотного займенника: Заткайся, заткала би тя лиха година [с. 35]; - Ая-ая, Марійо... щзо не сподівалася - то не сподівалася, так мені ся получило [с. 33]. Давні форми зворотного займенника модифікувалися в сучасній мові в частку, що стала формальним показником дієслів зворотно-середнього стану, їхнім структурним компонентом. Носії буковинських говірок (і не тільки!) залишили за цим елементом первинне навантаження, а відтак, як свідчить i текст роману, використовують його як у препозиції (Та й устидали би ся навіть думати, щзо дитина не Михайлова [с. 90]), так і в постпозиції до дієслова (Правда, в Курика громада дітей тут ся лишила...[с. 105]; I може тому таке ся причинило...[с. 115]). Подекуди він набуває й різних фонетичних варіацій: Станьте отутки та розкажіть до прикладу, щзо си робить, що ви такі, якби вам чіп у одне місие забив [с. 121]. Виразною говірковою ознакою $\epsilon$ наявність редуплікованих та редукованих граматичних займенникових форм: ...вигопкувалися гостинцями між двома войнами румунські жовніри, збиваючи кінськими копитами порохи на два сусідські села і на півсела з тамтого - польського - боку [с. 51]; Я тоді дитину через Курика скинула, шляк би'го був трафив ще в утробі, як 
він не одному тут життя перебив [с. 122]; -Чуєте, Йванихо, а щэо у вас такий вигляд, як би вас Цвичок цеї ночі обертав? [с. 42].

Мова роману «Солодка Даруся» ілюструє й уживання дієслівних форм минулого часу з залишками давнього перфекта (-A не чули'сте, Гафійко люба, ие правда, щэо Їлена законилася цеї ночі Цвичком? [с. 44]) чи аориста (...Щось буду казати вам, Михайлику тречний, але не майте на мене зла за ие казання, бо то є свята правдичка, абих так до завтра дочекала [с. 113] (пор.: дієслово бути в аористі - Быхұ, бы, бы (однина), быхомұ, бысте, быша (множина) і т. ін.), особові форми теперішнього (майбутнього) часу 3 різними модифікаціями: -Бо не знаю, щэо там діється у тій проклятій хаті, а я жию по сусідству. Так щзо печуся задля свого спокою і справедливости [с. 69] (імовірно, пов'язано з польською мовою; пор.: żyju - живу; niech żуje - хай живе і т. ін.); ...Не хочу грішити, кумко-любко, але здаєми'ся, що з тою Матронкою щуось нечисте замішано... [с. 115] (пор.: здається мені; здаєми'ся складається 3 трьох елементів здає + ми $(=$ мені $)+c я) ;$ Не позволям! - рубанув повітря рукою Цвичок $і$ вийшов з кабінету [с. 55]; Моя мені точно скаже: «Не позволям». А ваша що - позволям? [с. 104] (у східнослов'янських мовах давне закінчення -мь (-м) (їм, дам, розповім) залишилося тільки в межах нетематичних дієслів, тоді як в інших слов'янських мовах це закінчення поширилося за аналогією на десятки й сотні слів зі значенням процесуальної ознаки, які первісно мали в кінці $о$-носове (пор.: падаю, знаю; пол.: padam, znam; чес.: padám, znám).

Говірковою рисою можна вважати й надлишковість видільних часток (лиш, тілько), до того ж остання має й відмінне від літературної мови граматичне оформлення: А Даруся лежала, не реагуючи ані на світло, ані на звук - лиш тілько щчо не була мертва [с. 75]; -E-е-е.. казали оногде старі люде: не можна так дуже любитися, як иі двоє любилися, - на людей не зважали... бо ніхто, навіть Бог, не любить, коли людина жиє - $i$ лиш тілько тішиться [с. 116-117]. За таким же зразком оформляється й числівник стільки: Та й як я скажу людям, що через твою дурну голову вони позбулися стілько праціi?[с. 95]. Вирізняється й регіональні здебільшого похідні прийменники: Даруся дивилася на те все з вікна почерез фіранок [с. 49]; А на ранок дивиться почерез паркан: якщо Даруся обходить город, то можна у возниці класти вогонь [с. 23]; Даруся викладає з кошика припасене добро довкруг хреста...[с. 31], а також різноманітні регіональні вигуки: - Аzій на таке чудо! Усі допитуються, у кого взяла та в кого... ще наврочать мені врожай, - не розгинаючись від грядки, відповідає - нібито сердиться - Марія [с. 10], де агій уживається для висловлення обурення, роздратування, незадоволення; $\boldsymbol{A д и , ~ п а к у ю т ь ~}$ зараз на фіри [с. 123], де ади висловлює здивування, вступає в синонімічні відношення $з$ літературними словами «дивись», «бачиш»; Він перший раз за багато років почув, щэо в нього є серие - $i$ крикнув коневі «гайта»... 
[c. 166], тобто «гаття», уживається для підганяння коней або як наказ коням повернути праворуч.

Щодо синтаксичних граматичних діалектних особливостей, то на увагу заслуговують передовсім такі, як-от: відсутність координації між підметом і присудком (-Дурне - не дурне, але так мене мама-покійниця вчили, дай, Боже, їй иарство небесне [с. 91]) і відмінності граматичної форми керованого відмінка (Усе лихе минулося, поблідло, втратило ясність, а туга за чимось далеким лишилася в Дарусиній голові такою гострою, щзо від того вона болить їі [с. 31]; Серие серием, але коли Іванова дримба здобувалася на голос, Дарусю ніколи не боліла голова [c. 46]; Вас болить голова, Матронко? - тихесенько питав Михайло, прикладаючи до чола долоню [с. 118]).

Загальновідомо, що місцеві діалекти відображають глибинні процеси безперервного розвитку і зміни загальнонародної мови, які найвиразніше виявляються в лексиці. А відтак цілком закономірно, що й «Солодка Даруся» репрезентує велику кількість тих говіркових елементів, які отримали кваліфікацію лексичних діалектизмів. Це здебільшого «слова діалектного вжитку, що позначають поняття, для вираження яких у загальнонародній мові вживаються назви, утворені від іншої непохідної основи» [9, с. 183]. Така територіально обмежена лексика виявляє семантичну тотожність у межах означуваних понять зі словами літературної мови й відрізняється від останніх матеріальною (звуковою) оболонкою, інакше кажучи, має тотожний план змісту при нетотожному плані вираження. Наприклад: Тато взяв тоді свого бука, припрятаного на всяк випадок у хоромах, і дав Дарусі такого шміру по сращі, щуо вона півдня відсиджувалася у барабулинні поза стайнею [с. 20], де барабулиння «картоплиння» похідне від барабуля (бараболя), дериваційна база ймовірно пов'язана 3 назвою міста Бранденбург;...аж шкіра на ногах морщичться, як сушениця після коптіння на возниці [с. 64], де возниця «дерев'яна споруда для сушіння фруктів»; аналогічний звуковий комплекс використовується й для позначення «приміщення, де коптять м'ясо димом», вступає у синонімічні відношення 3 лексемою бужарня (...nовідомив Танасій Максим'юк, який у Конятин не евакуювався, а переховувався в селі- у свойй бужарні-возниці [с. 143]); Обголили в районі Івана на бубон, дали замість дримби дряпак у руки - $i$ пімов Цвичок замітати вулиці райцентру [с. 74], де дряпак - «старий віник»; Особливо, коли парубок бере сторонську, а не свою, сільську, дівку і роззирає ії вночі $i$ вдень з усіх боків, як писанку, писану в чужому селі [с. 81], де сторонська - «та, яка походить з іншої місцевості, так би мовити, «зі сторони»; A nid вечір візьме дитину на руки, колише, стиха приспівуючи, - $i$ ближче до брами перебереться: Михайла з деньки визирає [с. 92], де деньки «робочий день; щоденна праця» (пор.: денькувати - «працювати щоденно»); Так що сільські люди намагалися пантрувати худобу в лузі, 
обклавши воринням місие від дамби [с. 100], де вориння - «огорожа 3 ворин» (ворина - «жердина для огорожі»).

Мова роману переконливо засвідчує і те, що буковинська говірка ілюструє результати контактування 3 сусідніми мовами, здебільшого 3 польською та німецькою. Наприклад: Брама тут завжди замкнена на дерев'яний патичок [с. 28] (пор. пол.: patyczek); Собаки, поопускавши писки, стоять півколом біля Дарусі, ніби сторожують [с. 28] (пор. пол.: pysk - «морда, пика»); Та Іван частенько завертав Маріїні попоїдки, показуючи на баняк звареної бараболі чи чавун кулеші [с. 47] (пор. пол.: baniak); Дві великі кані, визираючи собі здобич, висіли над Михайловою хатою, що сусідила з Маріӥною [с. 126], де каня - «шуліка» (рос.: коршун) (пор. пол.: kania); - На добре, таздиньки, бо скілько того життя? Кавальчик! [с. 83], де кавальчик - «маленький шматочок» (пор. пол.: kawateczek); В селі декотрі газдівські дівки не годні приховати від людських очей, що зайшли в передчасну тяж, хоч затискалися поясами $i$ широкі спідниці з фалдами носили, а порядна шлюбна жінка, та ще така дрібна, що й не знати, де тота дитина в ній вмістилася, мало не до Покрови город обходила, щонеділі рівненько шпрунькала до иеркви; $i$ черевики сама собі до послідніх днів шнурувала [с. 89], де фалда «складка» (пор. пол.: fatda); - А чи тобі, нензо лсста $i$ к... остатна, мозіль не зробився на отій твоїй поморщеній штуиі після весілля у Ріжні тої неділі, коли підфітькувала ногами на сіні коло иимбаліста, аж смереки ся жммурили з устиду, не то, щз люде? [с. 40], де лєстий - «найгірший» (пор. нім.: letzt - «останній»); Пропадає задурно чиясь прачя, а оцей, що $з$ твером, - показав очима на мілічіонера, - иього не видить [с. 54], де твер «Гвинтівка, зброя» (пор. нім.: Gewehr); Ти щзо, не видів, хто з фанами, синім та жовтим шитими, вибігав аж у Хорови зустрічати оцих опришків, що вже рік у селі порядкують? [c. 122], де фана - «прапор, корогва» (пор. нім.: die Fahne); A тут ще таке - нова влада селом спацірує та лиш кров холодить у жилах [c. 114] (пор. нім.: spazieren) тощо. Переважна частка таких регіональних лексем $\epsilon$ незрозумілими непредставникові відповідної говірки; з'ясування їхньої семантики потребує додаткових зусиль, зокрема вимагає роботи зі спеціальною довідковою літературою. Подекуди авторка пояснює ті чи ті лексичні діалектизми через покликання з ремаркою діал. (I як то можна було тікати від своєї крові, а все на крішечку такої маленької жінки, як Куричка, звалити? [с. 105] (крішечка - «дрібка»); I чує він якусь неясну тривогу, так, нібито зараз його має украсти оцей половик, щчо мертво висить над карком, як над мершею, ніби справді иілиться в саме тім'я [c. 105] (половик - «яструб» (імовірно, співвідноситься з дієсловом полювати (пор. пол.: polow); мериа - «мертвечина»; у тлумачному словнику супроводжується ремаркою зах. і витлумачується як «падло»). Особливо великою мірою це стосується слів зі значенням процесуальної 
ознаки: Аби язик по селу не пускала, та не мольфарила - а решта...най буде [с. 87] (мольфарити - «чаклувати»); Розбуджені зі сну сусіди знизували плечима: увесь день Матронка чипіла в городі [с. 93] (чипіти «бути нахиленим»); ...а я щее, видите, Марійо, тут, а ви вже й дитину вслонили, і корову здоїли, та й пішла з тим до себе, а відтоді Марія ї̈ не виділа, бо й сама затяглася до хати ззагоді...[с. 94] (вслонити «приспати»); Іншим разом курка розгребе грядку в сусідськім городі - а на другому краю села газдині вже вадяться про изю дурничку [с. 95] (вадитися - «сваритися, сперечатися»); Вікно Михайло ще два тижні тому відтраджсував мельникові, а крупи забрати не встигнув [с. 107] (відтраджсувати - «віднести, перемістити»); Флинькаю, Міську любий, бо, як надумаю, щзо нас усіх тут чекає, то й камінь би заплакав [с. 110] (флинькати - «плакати, схлипувати»); Ви би, Михайлику срібний, якось заглагоӥли дитину [с. 112] (заглагоїти - «заспокоїти»); Та й якої дідьчої мами було п'їланштся на дамбу, коли корови пасуться ближче до скалистого берега [с. 114] (п'їланитися - «лізти, дертися»); Груди спрутило від надлишку довго незціджуваного і запеклого молока [с. 115] (спрутити - «напнути»).

Десь-не-десь витлумачення лексичних діалектизмів подається безпосередньо в контексті, як-от: Ta ц̌ по правді сказати, сільські молодиці, ті, щзо були справді гонорові, чи такими себе вважали, гидували неклейдоватим, нехарапутним чоловіком, щзо людською мовою означало не дуже спритним, невдачливим, нефортунним [с. 43], чи то в межах того ж таки контексту вони вводяться в парадигматичні синонімічні відношення зі словом літературного вжитку: Не раз $і$ діти падали сторч головою, задивившись на шумливу воду, і худоба ішла на той світ із дамби, $i$ не одного контрабандиста, або, як кажуть по-тутешньому шварцівника, з того боку пристрелили отам, унизу [с. 100] тощо.

Незаперечним $є$ те, що лексичні діалектизми, репрезентовані письменницею, охоплюють здебільшого ті лексико-граматичні розряди слів, які науковцями кваліфікуються як самостійні. Найчастіше це слова зі значенням предметності (іменники) та значенням процесуальної ознаки (дієслова), значно рідше - слова зі значенням непроцесуальної ознаки прикметники i прислівники. Останні можна проілюструвати такими прикладами: Чи то перевізники були у змові зі стражами кордону, чи для заробітку подеколи невиправдано ризикували, чи тамтешні закони були трохи такі, як дишло...а може, те, щзо Черемошне тулилося у дідька за пазухою, то й дишло туди розверталося поволіше, ніж де-інде, але зрідка із шпаровитими тешефтарями траплялося саме так [с. 100], де шпаровитий - «винахідливий, метикуватий» (пор. також: тешефтяр < тешефрm (нім.: Geschäft - «справа»); Михайло того не розуміє, бо то газдівства не стосується, а його інтересує лиш робота і господарка, але, Боже прости, Курик у селі такий був каламітний, щуо щуе трохи - $i$ тут 
тюрму був би собі заробив [с. 104], де каламітний - «заводій» (пор.: каламутний - «неспокійний»; каламутник - «той, хто спричиняє неспокій»); Чоловіче, чи ти видів колись їх коло людей як будь, із латками, помняцканими, ніби $\ddot{i x}$ пси тягали [с. 110], де помняцканий «непрасований, пом'ятий».

Щодо дієслівної лексики, то слід зауважити: лише в поодиноких ситуаціях iї значення допомагає з'ясувати контекст: Мучилася перед смертю страшно - спокійнитися ніяк не годна була [с. 169], де спокійнитися - «померти; отримати вічний спокій» (пор.: спокійнитися $\leftarrow$ спокій); Люди часом люблять посмішкуватися 3 іншого, то й призвішкуються [с. 23], де призвішкуватися - «давати прізвисько». Іноді семантика може «вгадуватися», щоправда, етимологічні розвідки зазвичай дають змогу отримати й додаткову інформацію. Наприклад: -Cвят-святсвят... вони, кумко злотна, голі-голісінькі посеред ночі проти місяия у тепличці купаються $i$ не встидаються, щуо село спить... а вони село паплюжать. .. і тирлуються, певно, у воді... мало їм хати... нема на них міліиіі... люди добрі, хто таке у наш час видів?! [с. 63], де тирлуватися «займатися коханням»; значення виникло внаслідок переосмислення семантики: тирло - «місце, де паруються олені», тобто тирлуватися «паруватися»; A тоді дасть уже й побаювати. Бо навіть найлюдяніший храм у селі не є такий веселий, як Дарусин бай отут із татом [с. 30]; Добре, щзо сьогодні є з чим баювати! [с. 31], де значення дієслівних лексем баювати, побаювати допомагає встановити іменник бай «1) бесіда, мова; 2) забава, вечірка»; - Чи то [георгіни] в руки які недобрі дала, чи Варвара вночі вимикала, не мені вам, Марійо, казати, щзо то за відыма [с. 10], де вимикати - «вирвати» бере свої початки від прядильного виробництва; спершу за лексемою було закріплено значення «скубти» (пор.: миканка - «прядиво низької якості»); Замельдувати - замельдуй, але ні на кого твердо не сподівайся [с. 106], де замельдувати - «доповісти, повідомити» (пор. нім.: melden); Запустив роботи, на люди не показується, лиш жінку з дитиною пазить, так нібито ніхто до нього не мав гризоти [с. 116], де пазити - «пильнувати, доглядати» тощо.

Найбільша розмаїтість властива лексиці з частиномовним значенням предметності, або іменниковій. Вона охоплює такі основні тематичні групи:

1) назви осіб, що характеризують соціальний стан, родинні стосунки, вікові особливості і т. ін. (вуйко, любка, любас, шандар, фірман, першунка, батяр, совіти, маланкар, верстак тощо), наприклад: Гуиулка сяде собі в залиту сонцем траву на горбі чи десь під смерекою - $і$ світ ї̈ не колише: перебирає пальцем дримбу, $і$ ані Букінтемського палацу ій не треба, ні мужа, ні любаса, ані горілки [с. 41], де любас - «коханець» утворено від іменника люба (Ще дивіться, через таку любу згине чоловік [с. 116], тобто «через таке кохання») (пор. староукр.: июьы - «любов»); Ніж ото дітей 
отут пужати криком, краще би пішли изі батяри та добре діло зробили [с.54], де батяр - «гультяй, пройдисвіт»; Коли, хто і скільки правив по той бік ріки, Михайло не дуже знав, але знав точно, щя за його пам'яті муштрували там люд польські пани та іще шандарі чи жовніри [с. 97], де шандар - «жандарм»; - A чого не будете брати? Моїх верстаків забирають [с. 132], де верстак - «ровесник» утворено від слова верста, яке вступає в омонімічні відношення і за яким закріпилося застаріле значення «вік, вікова група»; Після закінчення промови перший брат Курика - Дмитро Угрин - підніс офіџерові хліб-сіль на вишитому рушникові [с. 129], де перший брат - «двоюрідний брат»;

2) назви предметів побуту, господарювання та харчування (тарчик, стая, дараба, фіра, драпак, вориння, міщулик, чір, фальч, ватра тощо), наприклад: Тата привалило дарабою, коли дитині було дванадиять років, а за три роки по тому й Михайлова мама пішла у глину через пусті бабські язики [с. 81], де дараба - «пліт, збитий із дерев'яних кругляків, для перевезення людей через річку» (пор. угор.: darab); Дехто, а особливо маєтні газди, усміхалися у вус і відмовляли - $і$ тоді, Михайло не міг би сказати, як таке трафилося, але він перечікував у травах чи під стаями доти, доки не можна було вкрасти з видного місия бодай кулачок масла чи тарчик сметани, і далі сідав на коня [с. 165], де стая - «постійне або тимчасове житло на полонині, у якому живуть пастухи влітку i переробляють молочні продукти»; тарчик - «невеличкий дерев'яний посуд для молочних продуктів - гуслянки або сметани» (імовірно, етимологічно споріднене зі словом тарнець - «1) дерев'яний посуд для молочних продуктів, об'ємом 4-8 літрів; 2) заст. міра рідини, що дорівнює 4 літрам» (пор. пол.: garniec); - Іще ззавидка Михайло відвів дитину до куми Марії, замкнув браму і хату на колітки, заставив вікна [с. 134], де колітки «замок»; Тебе твоя годує таким самим чіром, як пса, а Даруся мені грибочки у борщик кидає [с. 59], де чір - «рідка страва, переважно 3 кукурудзяної муки»; авторка витлумачує цю лексему, як «собача їжа, каша»); Дівки на відданню, трунту - ні пощеку, ані кавальчика, ані фальчі, а вони фани вишивали та людей баламутили [с. 122], де фальча - «сотка» (пор. давнє: «міра поверхні землі, яка дорівнює приблизно 114 сотих»);

3) назви для позначення абстрактних понять (бола, злоги, охіть, люба, помана тощо): Я свої як не пильнувала, а таки якась бола їх скосила [с. 10], де бола - «хвороба»; Село вкотре здивовано подивилося в бік їхньої з Михайлом хати: ніхто Матронки з черевом не видів, ні з ким вона про злоги не радилася, повитухи не кликали, а дитина плаче - аж надвір чути [с. 89], де злоги - «пологи»; -Уже як таке мене питаєте, то скажу по правді: ию охіть до гріха мені передала моя бабка, як весільний посаг [c. 44], де охіть - «бажання, прагнення або схильність до чого-небудь»; $A$ ви, пане директоре, як заступитеся за невинну душу, поману будете 
мати, ви ж християнин, а не безбожник [с. 55], де помана - «те, що дають на помин душі».

Крім власне лексичних діалектизмів, мова роману вирізняється й так званими етнографізмами, що являють собою назви місцевих реалій i понять, невідомих або не використовуваних поза межами відповідної говірки чи групи споріднених говорів, як-от: Зверху на вовняну кацавейку накинула половинку тертого-перетертого, давно вицвілого ліюнника [с. 25], де ліжнник - «домоткане ворсисте вовняне покривало з візерунком»; Сказати, щуо навіть тут, у горах, було багато охочих грати на дримбах не скажеш, бо час якийсь настав гейби не для веселості [с. 40], де дримба - «щипковий музичний інструмент, сила і висота звуку якого регулюються ротовою порожниною того, хто грає»; I притулились Михайло з Матронкою одне до одного так близько, щзо навіть через грубі їхні сардаки було чути прискорене биття сердецьь.. [с. 102], де сардак «верхній вовняний гуцульський одяг»; Видиш, ти щзодень ходиш у добріських свинських постолах. А на пролюдень маєш телячі вироб'стки [c. 110], де вироб’єтки - «святкові постоли з телячої шкіри».

Певні особливості демонструють і семантичні діалектизми - слова загальнонародної мови, які в місцевій говірці наділені специфічним значенням і сферою вживання. Наприклад: Зичити нікому нічого не зичили, бо лише складалися на господарку [с. 81], де господарка - «господарство» (пор.: господарка - «господиня»); Господарки було не стільки, щзоб дуже, але вже трохи було: корова, свиня, кури, троє товару дробу [с. 92], де дріб - «вівці» (пор.: дріб - «дрібні свинцеві кульки, що використовуються для стрільби з мисливської рушниці»); основне діалектне значення, за яким закріпився аналізований звуковий комплекс - «свійська птиця» (пор. пол.: $d r y b$ - «птиця»), однак словосполучення «троє товару дробу» вказує на те, що йдеться про «дрібний» товар (дрібні тварини), тобто вівці; Сиротливо потоптавиись на своєму подвір'ї, Михайло пішов до жидівської корчми купити нафти [с. 106], де нафта - «гас» (пор.: у загальнонародній мові таким звуковим комплексом позначають «мінеральну рідку оліїсту горючу речовину темно-бурого або чорного кольору, що залягає в надрах землі та вживається як паливо, а також як сировина для одержання ряду цінних продуктів, зокрема гасу, бензину»); Іван грав собі у дримбу в автобусі, а молодиця щуось йому криве сказала, відей, запитала, чи не холодно йому самому на автостанціях спати [с. 39], де кривий - «поганий»; Марія плакала і хитала головою, а далі потекла собі до хати [с. 75], де потекла - «пішла» тощо. Чимало 3 таких діалектизмів виникли внаслідок переосмислення семантики, процесів метафоризації (дріб, кривиц, потекла) та метонімізації (господарка, нафта).

У романі репрезентовано різні структурно-семантичні типи фразеологічних одиниць. Чимало 3 них відомі носіям мови, оскільки є кодифікованими. Наприклад: ... мало не все село дивилося-дивувалося, як 
Іван, скинувши картату сорочку, мало не півдня вимахував сокирою - ажс гай шумів [с. 44]; Бо світилися Цвичкові ребра крізь сорочку - і не знати, чи то фамілія його така була худа, чи то неприкаяне життя так висушило чоловіка [с. 47]; Яке їхало - таке й здибало [с. 47]; - Ти, мерзо мерзенна, приймаку дурний, безродне насіння, ти, дурню останній, щзо до такої самої пристав, ти злодію галіцейський, паскудо паскудна... я на тебе управу знайду... будеш сидіти за злодійство у криміналі - кістки зогниють тобі в нім [с. 50]; ...так і пішов малолітній Михайло служити по людях, годувати газдівські воші [с. 82]; Аби язик по селу не пускала, як воротило, та не мольфарила - а решта... най буде [с. 87]; Непусто люди кажуть: нема щцастя змалку, то й до останку [с. 106-107] і т. ін.

Однак, як свідчить мова роману, письменниця репрезентує відповідні зразки й так званих регіональних усталених конструкцій. Заслуговує на увагу в цьому плані прийменниково-іменникове сполучення слів, яке метафоризувалося, фразеологізувалося, стабілізувалося діалектним узусом і відтворюється в готовому вигляді, що, власне, ілюструється діалогічним мовленням: Ось уже й клуб. А щзоб провідати тата, коло клубу треба звернути поза Йорчиху, кажуть у селі. В оичій ось хаті праворуч теперішнього сільського клубу жила колись жінка. Чи то щзе за Австрії, чи за Румунії. Йорчихою звалася, бо чоловік у неї був Йорко. Мало хто пам'ятає, коли ті Йорки самі спокійнилися, чи хто їм поміг подякувати изьому світові. Давно чужі люди побудували на місиі Йоркової хати изілі хороми, народили й пошкодували діточок та й газдують собі як уміють, а до місия, якого в селі нікому не обминути, так і причепилося: поза Йорчихою [с. 27], тобто поза Йорчиху означає «на кладовище»; у поєднанні з різними процесувальними супровідниками прийменниковоіменникова конструкція набуває семантики - «померти»: - Bu, Докійко, нашчо ичі рушники купуєте? - Як нащзо?! Поза Йорчиху готуюся. - Та щзе рано вам, бійтеся Бога! - Ніколи не рано думати про завтра [с. 28]; Але люди не дуже квапляться просто так ходити поза Йорчиху [c. 28]; Чуєте, Марійо, роками нікому цуе не казала, а тепер вам скажу, бо можуть мене скоро віднести поза Йорчиху, то так з гріхом і лишуся [c. 33] тощо. Для позначення поняття «померти» Марія Матіос використовує й синонімічні конструкції, як-от: Тата привалило дарабою, коли дитині було дванадиять років, а за три роки по тому й Михайлова мама пішла у глину через пусті бабські язики [с. 81] (пор.: піти у землю).

В основній своїй масі усталені конструкції маніфестують загальновідомі трансформаційні процеси, що пов'язуються 3 поодинокими фонетичними (Як нова влада, Міську, приходить людям голови каламотити, то вона має бути степенна, спокійна, аби втихомирити народ [с. 111]), граматичними ( $A$ хто зробить не по-моєму, сам буде у ставу жсабів ловити [c. 12]) та великою мірою лексичними модифікаціями компонентного складу: А най мій язик чиряки обсиплють, 
яке дурне сказала [с. 10-11]; Вони таки не мають смальцю в голові, а Бога в череві, їі сусіди, бо думають, що вона дурна [с. 11]; Люди втікають від туги, яка заходить зашпорами в душу, як Тільки очі вихоплюють хрест [с. 31]; Ірина кричала так, що можна було подумати, вулищею йде колона евакуачійних підвод: слова їй зашпортувалися в роті, наче спіткалися об каміння [c. 50] тощо. Трансформація фразеологічних одиниць спостерігається як на рівні поширення компонентного складу (Вона так старанно приховувала, що вміс говорити, що часом сама не вірила у протилежне. Замикала двері, завімувала вікна, двома пальиями витягувала язик, брала дзеркало і дивилася-дивилася, ніби чекала, що слова самі підуть з горла пішки [с. 34]), так і на рівні лексичної субституції заміни компонентного складу: Не одна душа не раз дає ногам поля, коли біля Йорчихи чатують пси [с. 29] (пор.: дати ногам волю - «тікати» i дати ногам поля - «тікати в поле»); До того ж мав вроджену ваду: прирослий до піднебіння язик - $i$ через те його мова нагадувала торохтіння підводи по сільській вулиці... Може, тому й не любив пускати слово на люди [с. 42] (не любив пускати слово на вітер - «Говорити даремно» і не любив пускати слово на люди - «спілкуватися з людьми»); - Що вам скажу, Паютко... Наговорили ви тут три міхи і двоє бесаг чуда. Лиш не знати, де брехня, а де правда [с. 115] (пор.: наговорити три мішки гречаної вовни - «наговорити дурниць» і наговорити три міхи $\boldsymbol{i}$ двос бесаг чуда - «наобіцяти хтозна-чого»). Подекуди фразеологічна семантика зумовлюється контекстом: Ніхто у Черемошнім не знав 3 певністю, коли й де Йванові пуп рубали, де хрестили, хто його маматато, і чи має він бодай би який дім-двір чи кіл біля двору [с. 39] (тобто йдеться про те, де хтось народився, іншими словами, де йому пуп рубали). Подана ілюстрація маніфестує також натяк на фразеологічну одиницю $\boldsymbol{\mu i}$ двору ні тину (рос.: ни кола ни двора) - «чи має він бодай який дім-двір чи кіл біля двору». А десь-не-десь значення фразеологізму можна встановити лише після грунтовних етимологічних розвідок: $A$ maм, на тому боиі, плутається ногами котрийсь кучерявий тазда з набутку [с. 103], де набуток у буковинській говірці означає - «гостина, забава», звідси, відповідно, тазда з набутку - «газда, що повертається з гостини, забави», тобто «на підпитку».

Варто зауважити, що більшість регіональних фразеологізмів вирізняються експресивно-оцінним значенням, унаслідок чого служать для створення експресивного фону, репрезентують передусім зниженопросторічне забарвлення: ... вари чоловікові кулешу і тримай свою дямбу на заперті [с. 52]; ... а вас най совість замучить, як остатну нензу [с. 63]; ...а може, те, що Черемошне тулилося у дідька за пазухою, то й дишло туди розверталося поволіше, ніж деінде, але зрідка із шпаровитими тешефтярами траплялося саме так [с. 100]; Та й якої дідьчої мами було п '̈̈ланитися на дамбу, коли корови пасуться ближче до 
скалистого берега [с. 114]; ...mа й понесло їх з такими фанами перед батька в пекло, несла би їх лиха година [с. 122]; Ціла фамілія на пси зійшла [с. 168] тощо. Негативна оцінка забезпечується здебільшого наявністю відповідних компонентів у структурі тієї чи тієї фразеологічної одиниці. Наприклад: тримати свою дямбу на заперті (пор.: тримати свій рот на замку) означає «мовчати»; стилістично нейтральну лексему pom - компонент загальновідомої фразеологічної одиниці - замінено на зневажливу дямба < тємба < варта (зневажл. губа) [2, с. 33] (пор. пол.: warga); замучить, як остатну нензу, де ненза - лайл. зла, лайлива людина, виникло на основі переосмислення (ненза - нужда, злидні (пор. пол.: $n e ̨ d z a)$. Подібним функціонально-стилістичним навантаженням характеризуються й ті усталені конструкції, які виникли внаслідок деформації порівняльних зворотів: Хай тато краще питає, чого їі так довго не було, ніж має кривитися, щчо донька ходить, як фіра без дишла [c. 27]; А в Черемошнім колотилося, як під циганською спідницею [с. 119] i т. ін. Вони є стилістично виправданими, сприяють відтворенню місцевого колориту та індивідуалізації мови персонажів.

Отже, можна дискутувати над тим, доречним чи недоречним $є$ використання великої кількості діалектизмів у художньому творі, зрозумілі чи незрозумілі вони читачеві, порушують чи не порушують художньоестетичні вимоги твору і т. ін. Беззаперечним залишається одне: наявність діалектизмів у романі «Солодка Даруся» є аксіомою; вони є необхідним структурним компонентом тієї чи тієї конкретної ситуації. До того ж вміле оперування багатющим діалектним матеріалом допомогло письменниці реалістично змалювати життя і побут мешканців Черемошного, створити правдиві образи й деталі їхньої недалекої минувшини, подекуди пояснити відповідну поведінку, загалом же - поетапно розкрити людську трагедію, передусім трагедію сім'ї Ілащуків, а в особі цієї родини - трагедію всього буковинського народу.

\section{Література}

1. Бевзенко С. П. Українська діалектологія / С. П. Бевзенко. - К. : Вища школа, 1980. $-246 \mathrm{c}$.

2. Гуцульські говірки : Короткий словник / відпов. ред. Я. Закревська. - Львів, 1997. - $232 \mathrm{c.}$

3. Великий тлумачний словник сучасної української мови / [упорядн. та гол. ред. : В.Т.Бусел]. - К.; Ірпінь : ВТФ «Перун», 2001. - 1426 с.

4. Матвіяс І. Г. Українська мова і ії говори / І. Г. Матвіяс. - К. : Наукова думка, 1990. - 165c.

5. Матвіяс І. Г. Засади української діалектології / І. Г. Матвіяс // Мовознавство. 2000. - № 1. - С. 3-9.

6. Матіос М. Солодка Даруся : Драма на три життя / Марія Матіос. - Львів : ЛА «Піраміда», 2005. - [3-є вид.]. - 176 с. 
7. Німецько-український, українсько-німецький словник / [укладачі: 3. О. Баранець, В. Н. Бублик, О. В. Двухжилов та ін.; за ред. Е. І. Лисенко]. - К. : Феміна, 1994. - $736 \mathrm{c}$.

8. Словник : Польсько-український. Українсько-польський / [укладачі : А. Маленька, 3. Ландовські]. - К.; Ірпінь : ВТФ «Перун», 2007. - 848 с.

9. Сучасна українська літературна мова : Лексика і фразеологія / за заг. ред. І. К. Білодіда. - К. : Наукова думка, 1973. - 438 с. 